\title{
Forskjeller i henvisningsrater truer ikke målet om likeverdige helsetjenester
}

\author{
Det er vanlig å oppsummere statistikk ved å presentere for eksempel gjennomsnitt og varians (spredning). \\ Jeg viser i denne artikkelen, med henvisningsrater som eksempel, at slike mål kan ha svært begrenset nytte \\ til styringsformål.
}

Diskuter saken på blogg.tidsskriftet.no

Tilgangen på statistikk som beskriver helsetjenesten blir gradvis bedre, og forbedringene gjør det mulig å forske på faktorer som kan forklare allmennlegenes forskrivninger og henvisninger $(1,2)$. Stadig flere tar til orde for at informasjonen fra de stadig forbedrede registre skal benyttes aktivt i styringen av sektoren. I denne prosessen er det viktig å skille mellom nyttig og mindre nyttig informasjon, og trå varsomt med hensyn til tolkninger av beskrivende statistikk. Den tilgjengelige informasjonen kan lett bli overveldende. Derfor sammenfattes gjerne informasjonen ved å beregne gjennomsnitt og varians (spredning). Eksempelvis tar forfatterne av en nylig publisert originalartikkel i Tidsskriftet utgangspunkt i slike beregnede verdier som grunnlag for sine konklusjoner om at det må stilles strengere faglige krav til allmennlegene (3).

I eksemplet nedenfor skal vi se at en kommune som skiller seg ut med stor variasjon og høy gjennomsnittlig henvisningsrate kan ha færre unødvendige henvisninger og færre unnlatte nødvendige henvisninger enn gjennomsnittet. Motsatt kan en kommune som fremstår som en gjennomsnittskommune egentlig være den kommunen der behovet for lokalt forbedringsarbeid er aller størst. Eksemplet viser at det kan være en like god strategi å gjennomføre lokalt forbedringsarbeid i en tilfeldig valgt kommune som å implementere lokalt forbedringsarbeid der det er avdekket «atypiske» gjennomsnitt eller variasjon i henvisninger.

Det er lett å forestille seg situasjoner der gjennomsnittlig henvisningsrate for en enhet, for eksempel en kommune, er høyere enn gjennomsnittet av andre enheter samtidig som den burde vaert lavere, eller omvendt. Imidlertid er situasjoner der:

- Gjennomsnittlig henvisningsrate for en enhet er høyere enn gjennomsnittet av andre enheter, samtidig som den burde voert enda høyere, eller situasjoner der

- Gjennomsnittlig henvisningsrate for en enhet er lavere enn gjennomsnittet av andre enheter, samtidig som den burde vart enda lavere, en like viktig del av helheten.

Det er vanlig å regne det som en mer alvorlig medisinsk feil å unnlate å henvise en pasient som burde vært henvist enn å henvise en som ikke burde vært henvist. I det følgende antas det at begge typer av feil forekommer. Jeg skal ikke gå nærmere inn på begrepene «burde» og «ikke burde», eller diskutere når det er ønskelig å henvise.

\section{Et tenkt eksempel med fire kommuner}

Vi tenker oss et eksempel med fire kommuner med identisk pasientpopulasjon. I eksemplet holdes de medisinske tilstandene konstant ved å eksponere denne pasientpopulasjonen for fire forskjellige legepopulasjoner. Dette gjøres ved å la antallet henvisninger som i etterpåklokskapens lys fremstår som korrekte, være konstant over kommunene.

Tabell 1 viser at «idealet» for gjennomsnitt og varians til henvisningsratene er den samme i kommune A, B, C og D. Vi ser også at kommunene $\mathrm{A}, \mathrm{B}$ og $\mathrm{C}$ har identisk gjennomsnitt og standardavvik på en desimal nær. De færreste ville likevel hevde at legetjenesten er like god i de tre kommunene: Vi ser spesielt at mens legene i kommune B i gjennomsnitt hadde seks «manglende henvisninger», så var tallet på «manglende henvisninger» bare halvparten i kommune A. Kom- mune A hadde samtidig også færre såkalte «unødvendige henvisninger» enn kommune B. Tallene i tabellen er hentet fra e-tabell 2.

Vi ser altså at gjennomsnitt og varians for faktiske henvisningsrater i kommuner ikke er egnet til å belyse momenter knyttet til kostnader i spesialisthelsetjenesten. Det at henvisningsraten er høyest $\mathrm{i}$ kommune $\mathrm{D}$, betyr ikke at legene i kommune $\mathrm{D}$ belaster fellesskapet med større kostnader enn legene i de andre kommunene. Det lave tallet på unødvendige henvisninger i kommune D kan spare fellesskapet for store utgifter, uten at den høye observerte henvisningsraten gjenspeiler denne besparelsen.

På samme måte er ikke gjennomsnitt og varians for henvisningsrater egnet til å belyse momenter knyttet til pasienthelse. Det at henvisningsraten er like høy i kommune A og B betyr ikke at legene i kommune A og B generer like store helsegevinster til sin pasientpopulasjon. Det lave tallet på unødvendige henvisninger og utelatte henvisninger i kommune A, sammenliknet med kommune B, gjør at kommune A generer større helsegevinster til sin pasientpopulasjon. Større helsegevinster blir generert i kommune A fordi det er færre pasienter som går glipp av behandling som

Tabell 1 Et tenkt eksempel på fire kommuner med identisk pasientpopulasjon, men ulik legepopulasjon

Henvisninger dersom

det ikke var usikkerhet

Gjennomsnitt

(varians)

Kommune A

$$
11,3
$$

$(16,7)$

Kommune B

11,3

$(16,7)$

Kommune C

11,3

(16.7)

Kommune $D$

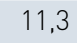

$(16,7)$
Faktisk henviste Gjennomsnitt (varians)

Burde ikke henvist. Gjennomsnitt (varians)

Burde i tillegg ha henvist. Gjennomsnitt (varians)

\section{3,7}

$(25,0)$

$(12,4)$

$(6,7)$ 
hadde vært nyttig. Dette gjenspeiles ikke i den observerte henvisningsraten.

Vi ser også at gjennomsnitt og varians i eksemplet ikke gir informasjon som er egnet til å vise hvor tilsynsmyndighetene bør sette inn sine ressurser. Det vil være like hensiktsmessig med tilfeldige stikkprøver som å gjennomføre tilsyn der man avdekker atypiske observasjoner. Grunnen er at det bak helt typiske tall for henvisningsrater kan skjule seg svært alvorlige forhold.

\section{Unødvendig og nødvendig}

Resonnementet i denne artikkelen om forskjeller i gjennomsnitt og varians for henvisningsrater mellom ulike kommuner gjør seg gjeldende også om man ser på forskjeller i disse målene for henvisningsrater mellom ulike leger.

Mens tall for unødvendige henvisninger og nødvendige, men unnlatte henvisninger ville vært nyttige fra et styringsperspektiv, så har tall på gjennomsnitt og varians for henvisningsrater i beste fall svært begrenset nytteverdi. Dette gjelder både tall fra enkeltleger og fra kommuner. Tall for unødvendige henvisninger og nødvendige, men unnlatte henvisninger vil trolig være vanskelig å skaffe til veie. For noen typer henvisninger vil likevel enheten det er blitt henvist til kunne vurdere hvorvidt en henvisning var unødvendig, eller om pasienten burde blitt henvist tidligere. Slik informasjon vil kanskje kunne være nyttig, men det er feilkilder også her. Trolig vil enkelte private aktører vise noe avdempet interesse for å melde fra om unødvendige henvisninger.

Det er altså ingen grunn til å tro at variasjoner $i$ henvisningsrater truer retten til likeverdige tjenester. Det finnes uendelig mange ulike medisinske praksisprofiler som gir ett og samme gjennomsnitt for henvisningsrater. Det er likevel grunn til å tro at omfanget av manglende henvisninger varierer, og at slik variasjon bidrar til at ulike pasienter opplever ulik kvalitet på de helsetjenestene de mottar.

\section{Geir Godager}

geir.godager@medisin.uio.no

Avdeling for helseledelse og helseøkonomi Universitetet i Oslo

og

Helse Sør-Øst kompetansesenter

for helsetjenesteforskning

Akershus universitetssykehus
Jeg takker Fredrik A. Gregersen for nyttige kommentarer til en tidligere versjon av manuskriptet.

e-tab 2 finnes kun i Tidsskriftets nettutgave.

Geir Godager (f. 1978) er cand.oecon, ph.d. og postdoktor ved avdeling for helseledelse og helseøkonomi, Institutt for helse- og samfunn ved Universitetet i Oslo og forsker ved Helse Sør-Øst kompetansesenter for helsetjenesteforskning.

Ingen oppgitte interessekonflikter.

\section{Litteratur}

1. Gjelstad S, Straand J, Dalen I et al. Do general practitioners' consultation rates influence their prescribing patterns of antibiotics for acute respiratory tract infections? J Antimicrob Chemother 2011: 66: 2425-33

2. Iversen T, Ma CA. Market conditions and general practitioners' referrals. Int J Health Care Finance Econ 2011; 11: 245-65.

3. Førde OH, Breidablik HJ, Øgar P. Truar skilnadene i tilvisingsratar målet om likeverdige helsetenester? Tidsskr Nor Legeforen 2011; 131: 1878-81.

Mottatt 8.12. 2011, første revisjon innsendt 2.1. 2012, godkjent 5.1. 2012. Medisinsk redaktør Merete Holtermann. 